\title{
Lactobacillus helveticus as a tool to change proteolysis and functionality in Swiss-type cheeses
}

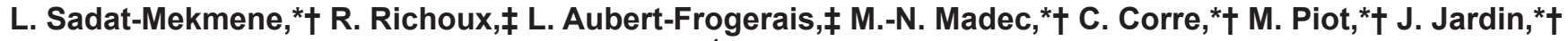 \\ S. le Feunteun,§\# S. Lortal, ${ }^{*} \dagger$ and V. Gagnaire ${ }^{*}{ }^{1}$ \\ *INRA, UMR1253, Science et Technologie du Lait et de l'CEuf, 65 rue de Saint Brieuc, F-35042 Rennes, France \\ †Agrocampus Ouest, UMR1253, Science et Technologie du Lait et de l'œEuf, 65 rue de Saint Brieuc, F-35042 Rennes, France \\ $\ddagger$ Actilait, BP 50915, 35009 Rennes Cedex, France \\ §INRA, UMR 782, Génie et microbiologie des procédés alimentaires, Site de Grignon, Bâtiment CBAI, F-78850 Thiverval-Grignon, France \\ \#AgroParisTech, UMR 782, Génie et microbiologie des procédés alimentaires, Site de Grignon, Bâtiment CBAl, F-78850 Thiverval-Grignon, \\ France
}

\section{ABSTRACT}

Lactobacillus helveticus exhibits a great biodiversity in terms of protease gene content, with 1 to 4 cell envelope proteinases. Among them, proteinases PrtH and PrtH2 were shown to have different cleavage specificity on pure $\alpha_{\mathrm{s} 1}$-casein. The aim of this work was to investigate the proteolytic activity of $2 \mathrm{~L}$. helveticus strains in cheese matrix: ITGLH77 (PrtH2 only) and ITGLH1 (at least 2 proteinases, PrtH and PrtH2). Cell viability, proteolysis, autolysis, and stretchability of experimental Emmental cheeses were measured during ripening. The peptides identified by mass spectrometry showed very different profiles in the 2 cheeses. Regardless of the casein origin, the number of different peptides containing more than 20 amino acids was greater in cheeses manufactured with strain ITGLH77. This accumulation of large peptides, including those from $\alpha_{s 1^{-}}$and $\alpha_{\mathrm{s} 2^{-}}$caseins, was in agreement with the lower overall extent of proteolysis obtained in ITGLH77 cheeses, which can be attributed to the presence of one cell envelope proteinase of the lactobacilli strains or lesser release of intracellular peptidases into the cheese aqueous phase. In parallel, stretchability was measured throughout ripening time. Emmental strands observed by confocal laser scanning microscopy showed microstructure similar to that of mozzarella strands. Stretchability was correlated with a specific type of peptide (hydrophobic), as shown by principal component analysis, and with a lower degree of proteolysis.

Key words: Lactobacillus helveticus, cell envelope proteinase, stretchability, peptide identification

Received September 20, 2012

Accepted December 3, 2012.

${ }^{1}$ Corresponding author: valerie.gagnaire@rennes.inra.fr

\section{INTRODUCTION}

Stretchability is a techno-functional characteristic of some cheeses, such as Emmental, Mozzarella, and Cheddar, and is one of the most desirable cooking properties for consumer products (e.g., pizza, pasta, fondue). Stretchability varies between cheeses depending on cheese-making processes, cheese composition, and ripening conditions used (Guinee, 2002). Stretching properties also depend on the presence of some species in the ecosystem, such as thermophilic lactobacilli (Hong et al., 1998; Guinee, 2002; Oommen et al., 2002; Richoux et al., 2009). It was demonstrated, for example, that Lactobacillus helveticus led to greater stretchability (3 times higher) than Lactobacillus delbrueckii (Richoux et al., 2009). Cell wall proteases of lactobacilli are thought to be important actors in generating stretching properties (Oberg et al., 1991; Oommen et al., 2002) via the release of hydrophobic medium-size peptides (Richoux et al., 2009). However, the relationship between cell wall proteinases of lactobacilli, proteolysis in cheese, and stretchability is far from being elucidated. This may be related to the high biodiversity exhibited by $L$. helveticus in terms of proteases gene content. Two cell envelope proteinases (CEP), PrtH and PrtH2, have been described in the L. helveticus CNRZ32 strain (Pederson et al., 1999; Smeianov et al., 2007) and extensively studied in 29 strains from various biotopes; PrtH2 has been shown to be ubiquitous, whereas the presence of PrtH appears to be strain dependent (Genay et al., 2009). In terms of activity, the presence of 1 or 2 proteases does not increase the overall extent of proteolysis on milk or synthetic substrate. However, several regions of the pure $\alpha_{s 1}-\mathrm{CN}$ are hydrolyzed only by strains exhibiting both proteases at minimum, suggesting a synergistic effect (Sadat-Mekmene et al., 2011). Recently, Broadbent et al. (2011) published an extensive screening of PrtH genes in L. helveticus showing that 1 to 4 proteases genes 
can be present per strain. Genes encoding PrtH2 and PrtH3 are highly similar, with about $70 \%$ homology, whereas PrtH and PrtH4 are clearly different proteases, with a conserved region of $45 \%$ similarity at the amino acid level. Further study is still required to fully explain how, in cheese, the texture and functionalities can vary when different proteolytic systems are involved.

The aim of this work was to investigate, in experimental Swiss-type cheeses, the proteolytic activity of $L$. helveticus in 2 strains possessing different CEP content: ITGLH77 (PrtH2 only) and ITGLH1 (PrtH2 and PrtH, at least; Genay et al., 2009). The peptide fraction was analyzed by different methods, including identification of cleavage sites by tandem mass spectrometry (MS/ MS). As peptidases released through autolysis can significantly modulate the size and number of peptides (Gagnaire et al., 1998; Valence et al., 1998), extent of lysis was verified using 2 intracellular markers. Except for the work of Richoux et al. (2009), no data exist in the literature regarding the dynamics of this stretchability for experimental Swiss-type cheeses. Stretchability was thus determined at different times of ripening. Principal component analysis was then performed in an attempt to clarify complex relationships between proteolysis due to L. helveticus and stretchability.

\section{MATERIALS AND METHODS}

\section{Cheese Making}

Two sets of cheeses were manufactured in parallel, using strain L. helveticus ITGLH77 or strain L. helveticus ITGLH1. Cheese making was repeated the next day from the same batch of milk. The pasteurized skim milk was micro-filtered and standardized with heattreated cream $\left(115^{\circ} \mathrm{C}\right.$ for $\left.20 \mathrm{~s}\right)$ using a standardized process as described by Richoux et al. (2008). One hundred kilograms of milk was matured at $32^{\circ} \mathrm{C}$ for 30 min after adding $0.03 \%$ (vol/wt) of a $50 \%$ calcium dichloride solution, $0.001 \%$ (wt/wt) of propionic starter (PAL-ITGP9, Standa, Caen, France), 0.12\% (vol/wt) of Streptococcus thermophilus culture [PAL-ITG 20/87 (Standa) cultured at $43^{\circ} \mathrm{C}$ for $5 \mathrm{~h}$ in Marstar $412 \mathrm{~A}$ (Danisco, Dangé Saint Romain, France)], and 0.03\% (vol/wt) of L. helveticus culture (ITGLH1 or ITGLH77 cultured on Phagex Lb, Standa).

Milk was coagulated at $32^{\circ} \mathrm{C}$ by addition of $30 \mathrm{~mL}$ of calf rennet (Berthelot, ABIA, Beaune, France). After cutting the curd into grains with a mean diameter of $3.5 \mathrm{~mm}$, the whey-curd mixture was cooked at $54^{\circ} \mathrm{C}$ for $25 \mathrm{~min}$. The duration of stir-out was $30 \mathrm{~min}$. The curd grains were then drained off and poured into $35-\mathrm{cm}-\mathrm{di}-$ ameter molds and pressed for $2 \mathrm{~h}$ in a thermo-regulated room at $36^{\circ} \mathrm{C}$. The acidification step was conducted for
$24 \mathrm{~h}$. The cheeses $(8 \mathrm{~kg})$ were then cooled and salted for $18 \mathrm{~h}$ in $\mathrm{NaCl}$-saturated brine at $11^{\circ} \mathrm{C}$. The cheeses were cut into 8 portions (1 $\mathrm{kg}$ each), wrapped under vacuum in BK1L ripening bags (Cryovac, Epernon, France), and ripened at $12^{\circ} \mathrm{C}$ for $20 \mathrm{~d}$ (cold room) and then at $24^{\circ} \mathrm{C}$ for $21 \mathrm{~d}$ (warm room). Hereafter, the cheeses manufactured using L. helveticus ITGLH77 and ITGLH1 as starters are designated H77 and H1 cheeses, respectively.

\section{Cheese Analysis}

Emmental cheeses were analyzed for moisture (IDF, 2004), fat (Heiss, 1961), and calcium (Pearce, 1977), and enumeration of the L. helveticus flora was performed according to the methods described by Thierry et al. (1998). Under a sterile atmosphere, Emmental cheeses were collected at d 1 (after pressing), 2 (after brining), 6 and 13 (during ripening in the cold room at $12^{\circ} \mathrm{C}$ ), 20 (when cheeses were transferred into the warm room), 23, 27, and 34 (during ripening in the warm room at $24^{\circ} \mathrm{C}$ ), and 41 (at the end of the warm room period). Ten grams of grated Emmental cheese was dispersed in $90 \mathrm{~mL}$ of sodium citrate $(20 \mathrm{~g} / \mathrm{L})$ in a bag and crushed in the Smasher (AES Laboratoire, Bruz, France) for $4 \mathrm{~min}$; from this solution the bacterial cell counts were made. Cheese proteolysis was assessed by determination of total nitrogen ( $\mathbf{T N}$ ), $\mathrm{pH} 4.6$ soluble nitrogen (SN), and 12\% NPN according to Gripon et al. (1975) using the Kjeldahl method (IDF, 2001).

\section{Measurement of the Cheese Stretchability}

Cheese stretchability (3 replicates per sample) was assayed by a method involving vertical traction of the cheese melted at $82^{\circ} \mathrm{C}$ according to Richoux et al. (2001). The length $(\mathrm{mm})$ of strands of heated cheese was measured at the breaking point of the stretched strand.

\section{Microstructure of the Strands}

The microstructure of the strands of Emmental cheeses was visualized using an inverted microscope Nikon Eclipse-TE2000-C1si (Nikon, Champigny sur Marne, France) allowing confocal laser scanning microscopy. Confocal experiments were performed using an argon laser operating at $488 \mathrm{~nm}$ excitation wavelength (emission was detected between 500 and 530 $\mathrm{nm}$ ) and a helium-neon laser operating at $543 \mathrm{~nm}$ wavelength excitation (emission was detected between 565 and $615 \mathrm{~nm}$ ). The observations were performed on $5 \mathrm{~mm}$, newly formed strands using one $10 \times$ (numerical aperture 0.45 ) and one $40 \times$ (numerical aperture 1.33) 
oil immersion objectives. Proteins were stained using Syto 9 (Invitrogen, Cergy Pontoise, France) and fat using Nile red (Invitrogen). Both stains were mixed together (Syto 9:Nile red, 3:1) and $10 \mu \mathrm{L}$ was added at the surface of the strands for $30 \mathrm{~min}$ at $20^{\circ} \mathrm{C}$. Bacterial colonies were visualized by using the Live/Dead BacLight Bacterial Viability Kit using the Syto 9 dye and propidium iodide (Invitrogen).

\section{Preparation of the Cheese Water-Soluble Extracts}

Cheese aqueous phases were prepared by adding $40 \mathrm{~g}$ of distilled water to $10 \mathrm{~g}$ of grated Emmental according to the method of Kuchroo and Fox (1982); the mix was blended using an Ultra Turrax blender (IKAT18 basic, Staufen, Germany) for 3 min at 20,500 rpm and further stirred for $30 \mathrm{~min}$ at $40^{\circ} \mathrm{C}$. Emmental samples were centrifuged at $6,000 \times g$ for $30 \mathrm{~min}$ at $4^{\circ} \mathrm{C}$ (Centrifuge Heraeus/Kendro Biofuge Primo R, Courtabœuf, France) to separate the aqueous phase from the pelleted caseins. Fat was eliminated and aqueous phase was filtered on Whatman filter paper 40 at $4^{\circ} \mathrm{C}$ and frozen at $-20^{\circ} \mathrm{C}$ until further use.

\section{Determination of the Casein Hydrolysis}

Casein hydrolysis was evaluated by urea-PAGE of the insoluble $\mathrm{pH} 4.6$ nitrogen fraction according to Collin et al. (1987). These fractions were expressed as the percentage of TN (determined using the Kjeldahl method).

The peptide pattern of the cheese water-soluble extracts (WSE) was analyzed by SDS-PAGE as described by Schagger and von Jagow (1987) using Protean II system $(16 \times 16 \times 0.1 \mathrm{~cm}$; BioRad, Marnesla-Coquette, France) with SDS/Tris/Tricine buffer and a concentration gradient from 12 to $18 \%$ of acrylamide used according to Sadat-Mekmene et al. (2011).

\section{Peptide Identification}

Peptides contained in the cheese WSE were separated by reverse phase-HPLC (2695 separation module with 2487 detector, Waters Alliance, Saint Quentin en Yvelines, France) with a Vydac C18 column (4.6 mm i.d. $\times 250 \mathrm{~mm}$ ), fitted with a precolumn containing the same phase. Separation was performed using solvent A $[0.106 \%$ trifluoroacetic acid (TFA; vol/vol) in MilliQ purified water $]$ and solvent B [0.1\% TFA (vol/vol), $80 \%$ acetonitrile ( $\mathrm{vol} / \mathrm{vol}$ ), in MilliQ purified water] under conditions of a linear gradient from 5 to $60 \%$ solvent B using a flow rate of $1 \mathrm{~mL} / \mathrm{min}$ at $40^{\circ} \mathrm{C}$ and a double detection at 214 and $280 \mathrm{~nm}$. One hundred microliters of the cheese WSE was injected onto the column and
3 fractions were collected as a function of the elution time: fraction A was collected from 2 to $22 \mathrm{~min}$, fraction B from 22 to $42 \mathrm{~min}$, and fraction C from 42 to 65 min. Each fraction was concentrated by speed vacuum before peptide identification by MS/MS.

The MS experiments were performed using a nanoRSLC Dionex U3000 system fitted to a QSTAR XL (MDS SCIEX, Ontario, Canada) equipped with a nanoelectrospray ion source (Proxeon Biosystems A/S, Odense, Denmark). The instrument was externally calibrated with a multi-point calibration using fragment ions that resulted from the collision-induced decomposition of a peptide from $\beta$-casein, $\beta-\mathrm{CN}(193-209)$. A preliminary sample concentration step was performed on a reverse phase column PepMap 100 [C18, $5 \mu \mathrm{m}, 300$ $\mu \mathrm{m}$ i.d. $\times 5 \mathrm{~mm}$ length; LC-Packings, Dionex, Amsterdam, the Netherlands]. Separation was performed on a reverse-phase column PepMap 100 (C18, $3 \mu \mathrm{m}, 75 \mu \mathrm{m}$ i.d. $\times 250 \mathrm{~mm}$ length; Dionex) at $35^{\circ} \mathrm{C}$ using solvent A [2\% (vol/vol) acetonitrile, $0.08 \%$ (vol/vol) formic acid, and $0.01 \%$ (vol/vol) TFA in deionized water] and solvent B $[95 \%$ (vol/vol) acetonitrile, $0.08 \%$ (vol/vol) formic acid, and $0.01 \%$ (vol/vol) TFA in deionized water]. A separation gradient was adapted for each fraction as a function of their hydrophobicity: fraction A, 5 to $30 \%$ of solvent B in 45 min and 30 to $85 \%$ in 2 min; fraction B, 5 to $15 \%$ of solvent B in $3 \mathrm{~min}, 15$ to $40 \%$ in $42 \mathrm{~min}$, and 40 to $85 \%$ in $2 \mathrm{~min}$; fraction C, 5 to $25 \%$ of solvent $\mathrm{B}$ in $3 \mathrm{~min}, 25$ to $60 \%$ in $42 \mathrm{~min}$, and 60 to $85 \%$ in 2 min. Elution was performed at a flow rate of $0.3 \mu \mathrm{L} /$ min. Eluted peptides were directly electrosprayed into the mass spectrometer operated in positive mode. A full continuous MS scan was carried out followed by 3 data-dependent MS/MS. Spectra were collected in the selected mass range 350 to $2000 \mathrm{~m} / z$ for MS spectra and 60 to $2,000 \mathrm{~m} / z$ for MS/MS spectra. The first, second, and third most intense ions from the MS scan were selected individually for collision-induced dissociation $(1+$ to $4+$ charged ions were considered for the MS/MS analysis). The mass spectrometer was operated in datadependent mode, automatically switching between MS and MS/MS acquisition using Analyst QS 1.1 software (MDS Sciex, Concord, ON, Canada).

To identify peptides, all data (MS and MS/MS) were submitted to MASCOT (v.2.2, Matrix Science Ltd., London, UK). The search was performed against a homemade database dealing with major milk proteins, which represents a portion of the UniProtID database (Artimo et al., 2012). No specific enzyme cleavage was used and the peptide mass tolerance was set to $0.3 \mathrm{Da}$ for MS and 0.2 Da for MS/MS. Three variable modifications (phosphorylation on serine and threonine, oxidation of methionine, and deamidation of asparagines and glutamine residues) were selected. For each peptide 
identified, a minimum MASCOT score corresponding to a $P$-value below 0.05 was considered as a prerequisite for peptide validation.

\section{Calculation of Cleavage Scores Along the Protein Sequence}

To estimate the distribution of the cleavage sites along the casein sequences during cheese aging, a particular data analyzing procedure was used. A series of cleavage scores were calculated for $\alpha_{\mathrm{s} 1^{-}}, \alpha_{\mathrm{s} 2^{-}}$, and $\beta-\mathrm{CN}$ on the 6 samples (3 times of aging $\times 2$ strains) as follows. For each peptide identified by liquid chromatographyelectrospray ionization-tandem MS (LC-ESI-MS/MS), a score of 1 was attributed to the peptide bonds of the casein sequence that had to be hydrolyzed to release it; that is, the bonds that correspond to the N-terminal and C-terminal ends of the peptide - and a score of 0 was attributed to all other peptide bonds. This procedure was repeated for all the peptides identified, and the so-recovered series of scores (one for each peptide) were then added. At the end of the process, a series of scores representing the number of times (frequency) that a peptide bond had been identified as cleaved was thus obtained along the protein sequence. Results are presented by plotting the calculated scores according to the peptide bond positions of the studied protein. All these calculations were performed using homemade programs running with the Matlab software.

\section{Estimation of Cell Lysis}

Sodium citrate extracts of the cheeses were assayed for cell lysis by measuring the activity of aminopeptidases and lactate dehydrogenase (LDH) that are initially intracellularly located and can be released into the supernatant because of bacterial cell lysis during ripening. $\beta$-Naphtylamide $(\boldsymbol{\beta}-\mathbf{N a})$ derivatives were used according to Goldbarg and Rutenburg (1958): Lys $\beta-\mathrm{Na}$ for lysine aminopeptidase (PepN) and Phe-Proß-Na for X-prolyl-dipeptidyl aminopeptidase (PepX). The total LDH activity was assayed using pyruvate as substrate, as previously described (Cogan et al., 1981).

\section{Statistical Analyses}

Unilateral Student's tests were performed to compare the mean values of cheeses data manufactured using both strains. Principal component analysis was performed by using the StatBox software version 6.30 (GrimmerSoft, Paris, France) on the following data: Stretching; amounts of $\beta-, \gamma-, \alpha_{\mathrm{s} 1^{-}}$, and $\alpha_{\mathrm{s} 1}-\mathrm{I}-\mathrm{CN}$ determined by urea-PAGE; area of chromatographic fractions $\mathrm{A}, \mathrm{B}$, and $\mathrm{C} ; \mathrm{SN}, \mathrm{NPN}$, and nitrogen ratio
(SN-NPN/SN); PepX and PepN activities; and $\mathrm{pH}$ and bacterial count. Two independent sets of cheeses were manufactured and, for each data measured, 2 or 3 determinations per sample were done according to the protocol used.

\section{RESULTS}

\section{Chemical Analyses and Viability of Starters}

The composition of the cheeses $\mathrm{H} 1$ or $\mathrm{H} 77$ at the end of ripening (Table 1) fit well with the data already published on Emmental cheeses (Richoux et al., 2001, 2009). No significant differences were noted between final composition of the $\mathrm{H} 77$ and $\mathrm{H} 1$ cheeses $(P<0.05)$ regarding the following parameters: TS (\%), fat-in-DM (\%), moisture in nonfat substances (\%), and ratio of calcium to nonfat solids. Strains H77 and H1 were enumerated during cheese manufacture. Counts of $L$. helveticus decreased from $9.23 \log _{10}$ (cfu/g of cheese) at d 2 to 4.14 at d 41 for H77, and from $8.99 \log _{10}$ (cfu/g of cheese) at d 2 to 6.06 at $d 41$ for H1 (Table 1 ). The decrease in population of both strains was in agreement with data already observed by Valence et al. (2000).

\section{Bacterial Cell Lysis}

Bacterial cell lysis was measured by assaying intracellular LDH released into the cheese citrate extracts (Figure 1). Lower LDH activity was observed in H77 cheeses throughout ripening time as described by Valence et al. (2000). As a consequence of the lysis, other intracellular enzymes, such as aminopeptidases, were also released and 2 were assayed: PepX and PepN. Activity of PepX was 1.6 times lower in H77 cheese than in $\mathrm{H} 1$ cheese, whereas that of PepN was 1.5 times higher in $\mathrm{H} 77$ cheese than in $\mathrm{H} 1$ cheese. However, PepN activity was 3 to 7 times lower than PepX activity in $\mathrm{H} 77$ and $\mathrm{H} 1$ cheeses, respectively.

\section{Extent of Proteolysis}

The degree of cheese proteolysis was assessed by quantifying the nitrogen fractions; that is, TN, SN, and $12 \% \mathrm{NPN}$ - these latter 2 expressed as percentage of the TN (Table 1). The content of SN increased from 4.87 to $17.93 \%$ from 0 to $41 \mathrm{~d}$ of ripening in $\mathrm{H} 77$ cheese, and from 5.52 to $19.52 \%$ in $\mathrm{H} 1$ cheese (i.e., 1.1 times lower in $\mathrm{H} 77$ cheeses). Higher differences in the content of small peptides were observed between both cheeses as shown by the ratio NPN/SN (Table 1). Thus, in H77 cheeses the small peptides represented $44 \%$ the soluble peptides produced at d 1 and increased to only $52.2 \%$ at $\mathrm{d} 41$ of ripening. Consequently, the remaining 
Table 1. Composition of Emmental cheeses manufactured using strains of Lactobacillus helveticus ITGLH77 or ITGLH1 as starter ( $\mathrm{n}=2$ ) and evaluated after ripening for $41 \mathrm{~d}$

\begin{tabular}{|c|c|c|c|c|c|c|c|c|c|}
\hline \multirow[b]{2}{*}{ Strain and parameter ${ }^{1}$} & \multicolumn{4}{|c|}{ Cold room $\left(12^{\circ} \mathrm{C}\right)$} & \multicolumn{5}{|c|}{ Warm room $\left(24^{\circ} \mathrm{C}\right)$} \\
\hline & d 1 & $\mathrm{~d} 2$ & d 6 & d 13 & d 20 & d 23 & d 27 & d 34 & d 41 \\
\hline \multicolumn{10}{|l|}{$\begin{array}{l}\text { Strain ITGLH1 } \\
\text { ITH }\end{array}$} \\
\hline $\mathrm{pH}$ & $5.10 \pm 0.01$ & $5.21 \pm 0.01$ & $5.32 \pm 0.03$ & $5.34 \pm 0.02$ & $5.36 \pm 0.03$ & $5.33 \pm 0.03$ & $5.34 \pm 0.01$ & $5.41 \pm 0.03$ & $5.44 \pm 0.01$ \\
\hline $\begin{array}{l}\text { Lactobacilli counts } \\
\left(\log _{10} \mathrm{cfu} / \mathrm{g} \text { cheese }\right)\end{array}$ & - & $8.99 \pm 0.18$ & $7.72 \pm 0.21$ & $7.26 \pm 0.54$ & $7.06 \pm 0.12$ & $7.01 \pm 0.38$ & $6.19 \pm 0.15$ & $6.16 \pm 0.09$ & $6.06 \pm 0.03$ \\
\hline $\mathrm{SN} / \mathrm{TN}(\%)$ & $5.52^{\mathrm{a}} \pm 0.11$ & $6.29^{\mathrm{a}} \pm 0.70$ & $7.11^{\mathrm{a}} \pm 0.30$ & $8.03^{\mathrm{a}} \pm 0.14$ & $8.93^{\mathrm{a}} \pm 0.49$ & $10.72^{\mathrm{a}} \pm 0.12$ & $12.79^{\mathrm{a}} \pm 0.25$ & $15.59^{\mathrm{a}} \pm 0.39$ & $19.52^{\mathrm{a}} \pm 0.08$ \\
\hline NPN/TN $(\%)$ & $2.06^{\mathrm{a}} \pm 0.36$ & $3.40^{\mathrm{a}} \pm 0.18$ & - & $4.81^{\mathrm{a}} \pm 0.22$ & $5.66^{\mathrm{a}} \pm 0.33$ & $6.87^{\mathrm{a}} \pm 0.05$ & $8.43^{\mathrm{a}} \pm 0.56$ & $11.11^{\mathrm{a}} \pm 0.09$ & $14.41^{\mathrm{a}} \pm 0.20$ \\
\hline NPN/SN (\%) & $37.4^{\mathrm{a}} \pm 7.4$ & $51.3^{\mathrm{a}} \pm 3.2$ & - & $59.9^{\mathrm{a}} \pm 3.8$ & $63.4^{\mathrm{a}} \pm 0.3$ & $64.1^{\mathrm{a}} \pm 0.3$ & $65.9^{\mathrm{a}} \pm 3.0$ & $71.3^{\mathrm{a}} \pm 2.3$ & $73.8^{\mathrm{a}} \pm 0.7$ \\
\hline Total solid (\%) & & & & & & & & & $60.80^{\mathrm{a}} \pm 0.50$ \\
\hline FDM $(\%)$ & & & & & & & & & $46.00^{\mathrm{a}} \pm 0.40$ \\
\hline $\operatorname{MNFS}(\%)$ & & & & & & & & & $54.30^{\mathrm{a}} \pm 0.70$ \\
\hline CNFS (\%) & & & & & & & & & $3.10^{\mathrm{a}} \pm 0.04$ \\
\hline \multicolumn{10}{|l|}{ Strain ITGLH77 } \\
\hline $\mathrm{pH}$ & $5.11 \pm 0.01$ & $5.18 \pm 0.02$ & $5.31 \pm 0.04$ & $5.35 \pm 0.02$ & $5.38 \pm 0.04$ & $5.35 \pm 0.03$ & $5.31 \pm 0.03$ & $5.40 \pm 0.03$ & $5.42 \pm 0.01$ \\
\hline $\begin{array}{l}\text { Lactobacilli counts } \\
\text { (Log } 10 \mathrm{cfu} / \mathrm{g} \text { cheese })\end{array}$ & - & $9.23 \pm 0.05$ & $8.88 \pm 0.12$ & $8.82 \pm 0.42$ & $8.26 \pm 0.12$ & $7.13 \pm 0.38$ & $6.81 \pm 0.16$ & $5.00 \pm 0.06$ & $4.14 \pm 0.17$ \\
\hline SN/TN (\%) & $4.87^{\mathrm{a}} \pm 0.19$ & $5.59^{\mathrm{a}} \pm 0.48$ & $6.77^{\mathrm{a}} \pm 0.66$ & $6.86^{\mathrm{b}} \pm 0.05$ & $7.78^{\mathrm{b}} \pm 0.65$ & $9.18^{\mathrm{b}} \pm 0.24$ & $10.57^{\mathrm{b}} \pm 0.65$ & $14.30^{\mathrm{b}} \pm 0.61$ & $17.93^{\mathrm{b}} \pm 0.24$ \\
\hline NPN/TN (\%) & $1.42^{\mathrm{b}} \pm 0.00$ & $2.26^{\mathrm{b}} \pm 0.17$ & - & $2.95^{\mathrm{b}} \pm 0.02$ & $3.52^{\mathrm{b}} \pm 0.32$ & $4.09^{b} \pm 0.36$ & $4.95^{\mathrm{b}} \pm 0.40$ & $7.39^{\mathrm{b}} \pm 0.01$ & $9.37^{\mathrm{b}} \pm 0.43$ \\
\hline NPN/NCN (\%) & $29.2^{\mathrm{a}} \pm 1.2$ & $40.4^{\mathrm{b}} \pm 0.4$ & - & $43.0^{\mathrm{b}} \pm 0.6$ & $45.2^{\mathrm{b}} \pm 0.3$ & $44.5^{\mathrm{b}} \pm 2.8$ & $46.8^{\mathrm{b}} \pm 0.8$ & $51.7^{\mathrm{b}} \pm 2.3$ & $52.3^{\mathrm{b}} \pm 3.1$ \\
\hline Total solid (\%) & & & & & & & & & $60.60^{\mathrm{a}} \pm 0.50$ \\
\hline FDM $(\%)$ & & & & & & & & & $45.80^{\mathrm{a}} \pm 0.04$ \\
\hline MNFS (\%) & & & & & & & & & $54.50^{\mathrm{a}} \pm 0.07$ \\
\hline CNFS $(\%)$ & & & & & & & & & $2.90^{\mathrm{a}} \pm 0.03$ \\
\hline
\end{tabular}

a,b Means comparing $\mathrm{H} 1$ and $\mathrm{H} 77$ cheese composition at each ripening time with different superscripts differ $(P<0.05)$.

을 $\quad{ }^{1} \mathrm{SN} / \mathrm{TN}=\mathrm{pH} 4.6$-soluble $\mathrm{N}$ as a percentage of total $\mathrm{N} ; \mathrm{NPN} / \mathrm{TN}=12 \%$ TCA-soluble $\mathrm{N}$ as a percentage of total N; NPN/SN $=12 \%$ TCA-soluble $\mathrm{N}$ as a percentage of $\mathrm{pH}$ 4.6-soluble N; FDM = fat-in-DM; MNFS = moisture in nonfat substances; CNFS = calcium in nonfat solid. 
(A)

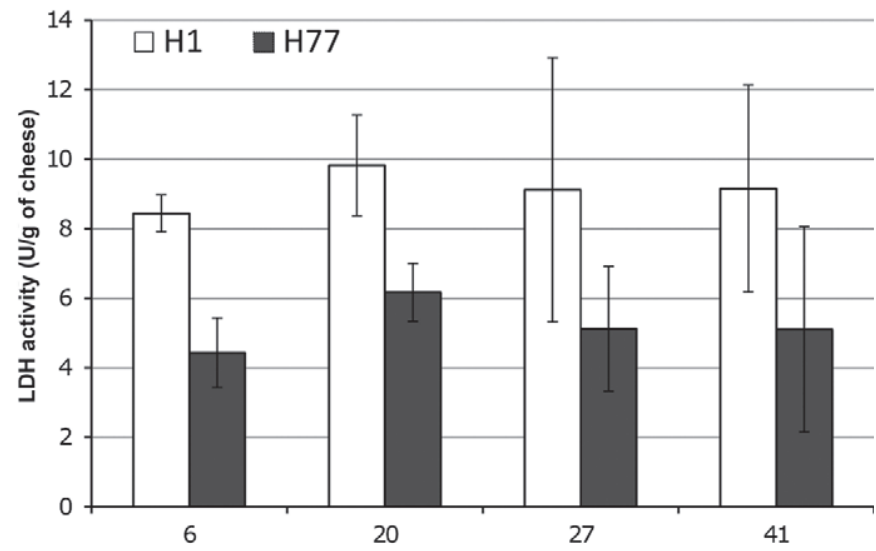

(B)

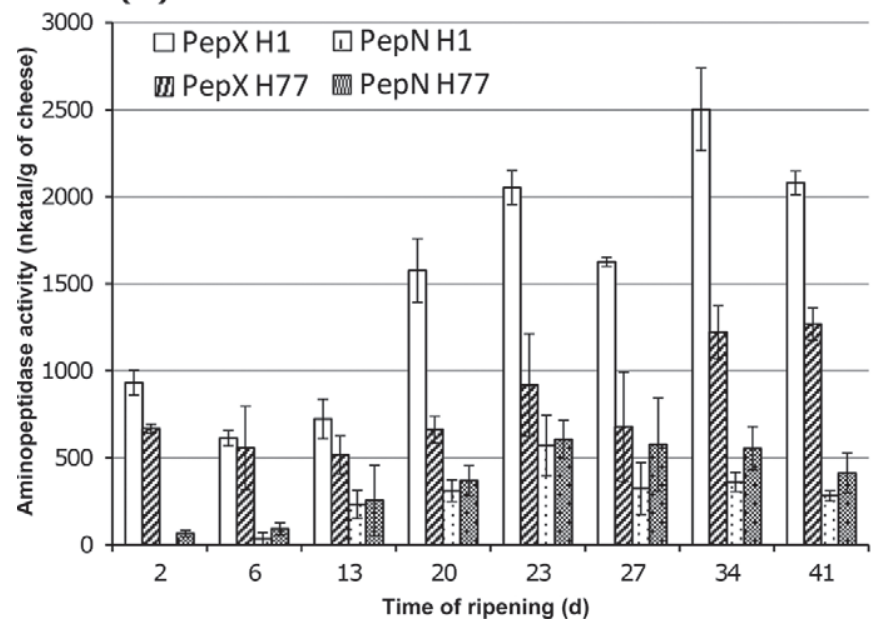

Figure 1. Changes in intracellular enzyme activities released during ripening in citrate cheese extracts of the experimental Emmental cheeses using the strains of Lactobacillus helveticus ITGLH1 and ITGLH77: (A) lactate dehydrogenase activity (LDH) and (B) aminopeptidase (PepX and PepN) activities.

peptides, $47.8 \%$, were composed of peptides insoluble in TCA $12 \%$, which corresponded to hydrophobic peptides having a size over 20 amino acids, according to Yvon et al. (1989). Conversely, the NPN/SN ratio in $\mathrm{H} 1$ cheeses varied greatly, from $37 \%$ at d 1 up to $73.8 \%$ at d 41(Table 1), showing a higher production of NPN in this cheese and indicating a different general pathway for the casein degradation.

\section{Casein Hydrolysis}

Primary proteolysis of $\alpha_{\mathrm{s} 1^{-}}$and $\beta$-CN, estimated by urea-PAGE, is shown in Figure 2. More than half of the $\alpha_{\mathrm{s} 1}-\mathrm{CN}$ was degraded at the end of ripening (i.e., 54 and $52 \%$ in $\mathrm{H} 77$ and $\mathrm{H} 1$ cheeses, respectively; Figure $2 \mathrm{~A}$ ), whereas $\beta$-CN was less degraded, only 39 and $43 \%$ in $\mathrm{H} 77$ and $\mathrm{H} 1$ cheeses, respectively (Figure 2B). The $\alpha_{\mathrm{s} 2}$-CN was completely hydrolyzed in both cheeses at the end of ripening (data not shown). No differences were observed between the kinetics of $\beta$-CN hydrolysis for both types of cheese. In contrast, differences were shown for $\alpha_{\mathrm{s} 1}$-CN with a linear decrease in $\mathrm{H} 1$ cheeses and a 2-step hydrolysis in H77 cheeses that can be described by the 2 following equations: $\mathrm{Y}_{1(\mathrm{\alpha s} 1-\mathrm{CN}) \mathrm{LH} 77}=$ $-0.07 \mathrm{x}_{1}+38.42\left(\mathrm{r}^{2}=0.30\right)$ between $\mathrm{d} 1$ and $\mathrm{d} 20$ (cold room $)$, and $\mathrm{Y}_{2(\alpha \mathrm{\alpha s} 1 \mathrm{CN}) \mathrm{LH} 77}=-0.88 \mathrm{x}_{2}+52.33\left(\mathrm{r}^{2}=0.96\right)$ between d 20 and d 41 (warm room). However, such a difference was not significant anymore at d 41 in terms of residual percentage of $\alpha_{s 1}-\mathrm{CN}$ in both cheeses.

\section{Peptide Analyses}

Insoluble Peptides. The production of $\alpha_{\mathrm{s} 1}-\mathrm{I}-\mathrm{CN}$ was detected by urea-PAGE after $20 \mathrm{~d}$ of ripening (Figure 2A) and was similar for both cheeses. Such a low production of $\alpha_{\mathrm{s} 1}-\mathrm{I}-\mathrm{CN}$ could be explained first by the inactivation of the rennet activity, which is the main enzyme hydrolyzing the bond $\mathrm{Phe}_{23}-\mathrm{Phe}_{24}$, and second by a higher pasteurization temperature $\left(78^{\circ} \mathrm{C}\right)$, which could have also reduced the residual activity of the milk

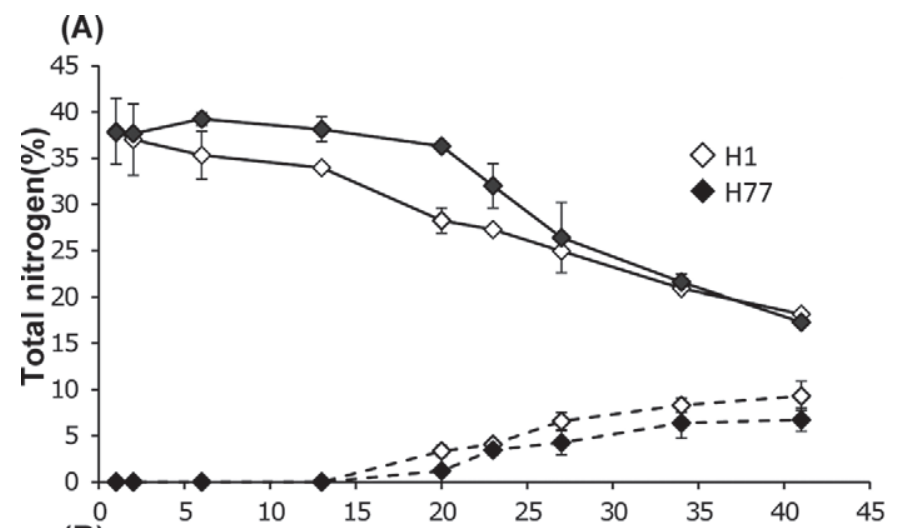

(B)

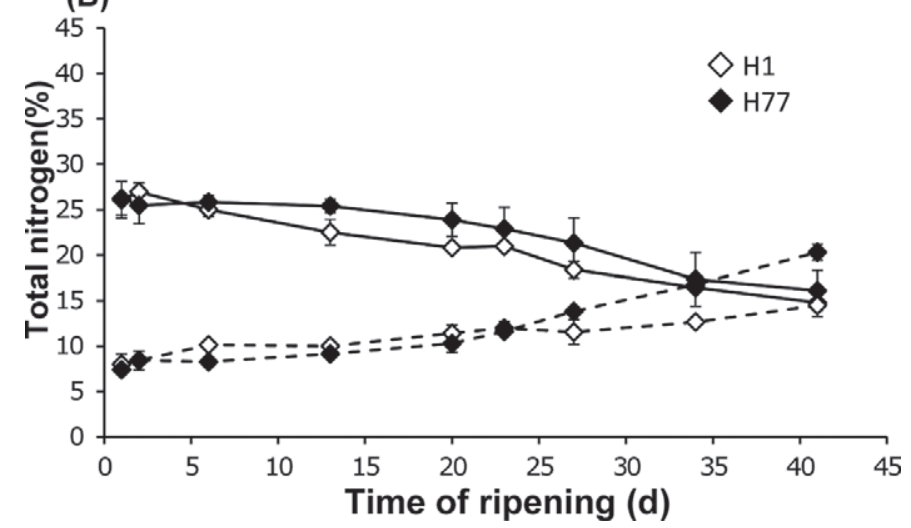

Figure 2. Changes in casein hydrolysis and oligopeptide production during ripening of Emmental cheeses manufactured using the strains of Lactobacillus helveticus ITGLH1 and ITGLH77: (A) solid line $=\alpha_{\mathrm{s} 1}$-casein; dashed line $=\alpha_{\mathrm{s} 1}$-I-casein; $(\mathrm{B})$ solid line $=\beta$-casein; dashed line $=\gamma$-casein. 
endogenous acid proteinase, the cathepsin D (Hayes et al., 2002). Therefore, the production of $\alpha_{\mathrm{s} 1} \mathrm{I}-\mathrm{CN}$ could be mainly attributed to the lactobacilli starters.

As expected in a plasmin-type cheese, $\gamma-\mathrm{CN}$ were already present at the beginning of ripening (Figure 2B).Their concentration increased from 8 to $20 \%$ from the beginning of ripening in $\mathrm{H} 77$ cheeses, two times more than that observed in $\mathrm{H} 1$ cheeses. As the same milk was used for both types of cheeses, the lower $\gamma$-CN concentration in $\mathrm{H} 1$ cheeses could be due to further degradation of these fragments by either proteinases or peptidases of H1.

Soluble Peptides. The peptides present in WSE of cheese using both strains of L. helveticus were analyzed by Tris/Tricine SDS-PAGE (Figure 3) and reversed phase chromatographic profiles (Figure 4).

For the peptides in the range from 2.5 to $25 \mathrm{kDa}$ of apparent molecular mass (Figure 3), main bands were common to both cheeses, exerting various intensities. Bands labeled a, b, and c were only present in cheese WSE of H77 cheeses, bands labeled d and e were only present in water soluble extracts of $\mathrm{H} 1$ cheeses (Figure $3)$. However, the main difference observed between both profiles was the higher intensity of some bands in the aqueous phases of cheese made with $\mathrm{H} 77$ throughout ripening, such as large-sized peptides (bands a, f, g, and

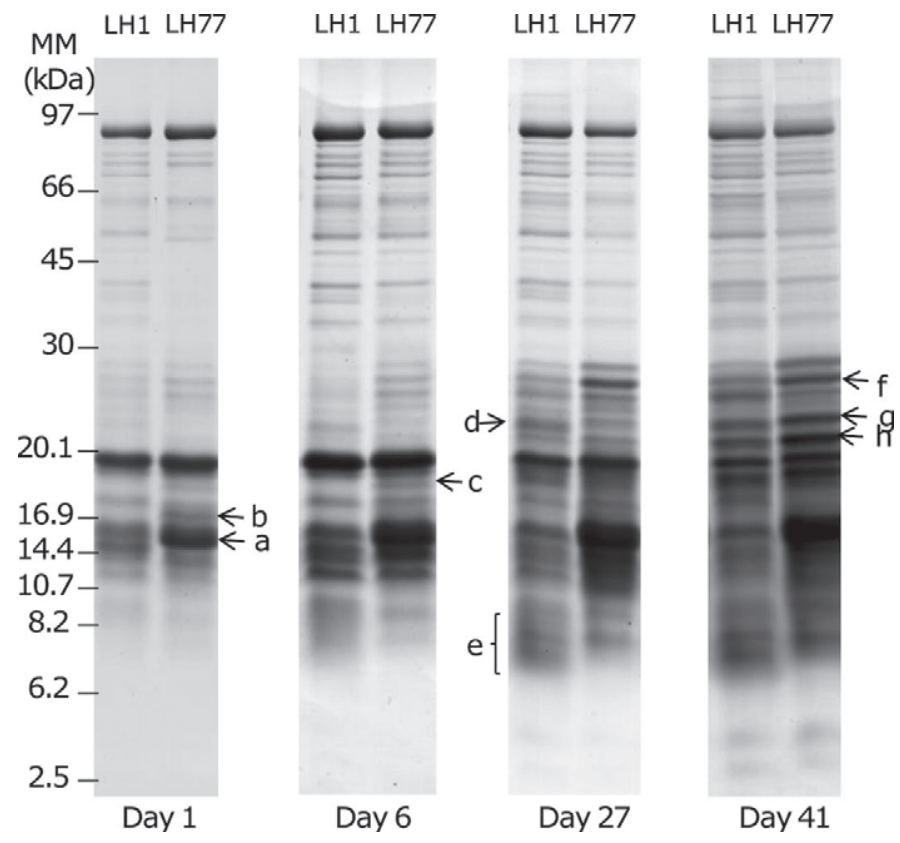

Figure 3. Tris/tricine SDS-PAGE electrophoregrams of watersoluble extract of Emmental cheeses manufactured using the strains Lactobacillus helveticus ITGLH1 and ITGLH77. MM = molecular mass marker. Letters a to $\mathrm{h}$ represent bands that were differentially present in the water-soluble extracts of Emmental cheeses: bands d and e were more intense or present only in $\mathrm{H} 1$ cheeses and the other lettered bands in H77 cheeses. h; Figure 3). As previously reported by Gagnaire et al. (2004), bands $>30 \mathrm{kDa}$ represent whey proteins (such as lactoferrin and BSA) and intracellular contents of bacterial cells, which appeared to be slightly more intense in the aqueous phases of $\mathrm{H} 1$ cheeses throughout ripening, in agreement with higher level of LDH released in cheese.

The RP-HPLC profiles of the cheese WSE showed changes throughout the ripening time (Figure 4, part A and B). The most hydrophilic peptides were the first eluted from the column (fraction A), and the most hydrophobic peptides were eluted in fraction $\mathrm{C}$; peptides in-between were eluted in fraction $\mathrm{B}$. At $\mathrm{d} 1$, fraction $\mathrm{C}$ (hydrophobic peptides) represented more than a half of the total area for H1 cheeses and two-thirds for $\mathrm{H} 77$ cheeses (Figure 4, part C). The percentage of area of this fraction decreased throughout the ripening time for both cheeses, but still remained above $45 \%$ for $\mathrm{H} 1$ cheeses and $60 \%$ for $\mathrm{H} 77$ cheeses at the end of ripening (Figure 4, part C). A subsequent increase of both fractions $\mathrm{A}$ and $\mathrm{B}$ was found for both cheeses. Nevertheless, regarding the H77 cheeses, fraction A did not exceed $15 \%$ throughout the ripening time, whereas fraction B reached 25\%, suggesting a higher production of peptides with average hydrophobicity. In the case of H1, fraction A increased to $29 \%$ of the total peak area, whereas fraction $\mathrm{B}$ reached $25 \%$ of the total peak area at the end of the ripening, showing a greater production of hydrophilic peptides in agreement with the percentage of NPN found (Table 1).

\section{Peptide Identification}

Peaks from fractions $\mathrm{A}, \mathrm{B}$, and $\mathrm{C}$ of cheese WSE at $\mathrm{d} 1,13$, and 41 were collected and identified by RP-HPLC coupled online with MS/MS (Supplemental Tables S1 to S3; available online at http://www. journalofdairyscience.org/). Very few peptides were identified in fraction A of cheese WSE, which contained mainly amino acids or peptides $<350$ Da corresponding to the minimum selected masses. More than 100 peptides were identified in fraction $\mathrm{B}$, and only around 30 were identified in fraction $\mathrm{C}$ of both cheeses. The peaks in fraction $\mathrm{C}$ are usually not well separated by RP-HPLC and therefore more difficult to identify by mass spectrometry.

The number of total peptides identified increased during ripening for both cheeses. At d 1 in $\mathrm{H} 1$ cheeses $70 \%$ of the identified peptides arose from $\beta-\mathrm{CN}$, whereas $19.8 \%$ were from $\alpha_{\mathrm{s}^{-}} \mathrm{CN}$, and $9.3 \%$ from $\alpha_{\mathrm{s} 2}-\mathrm{CN}$. This distribution changed during ripening, as $\beta-\mathrm{CN}$ represented $58.8 \%, \alpha_{\mathrm{s} 1}-\mathrm{CN} 27.5 \%$, and $\alpha_{\mathrm{s} 2}-\mathrm{CN} 13.7 \%$. In the case of $\mathrm{H} 77$ cheeses, $\beta-\mathrm{CN}$ was also the casein from which the identified peptides mainly derived (i.e., $54 \%$ 

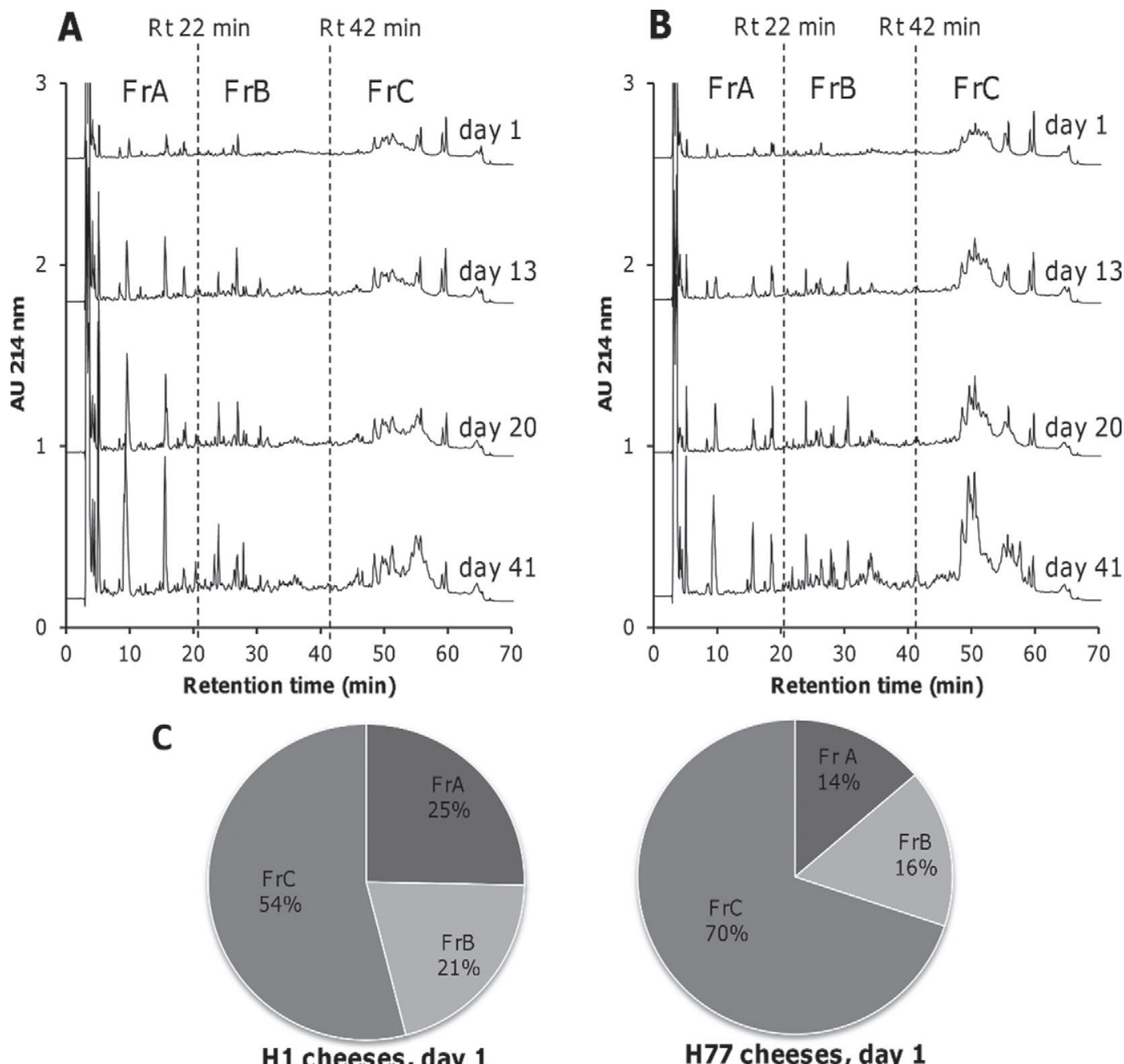

H77 cheeses, day 1

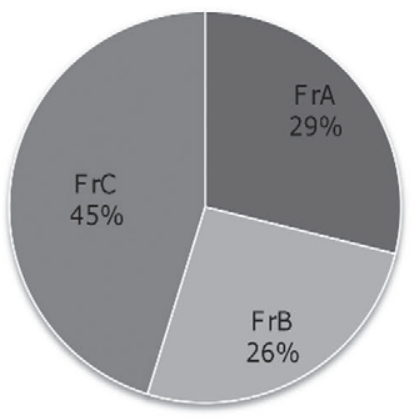

H1 cheeses, day 41

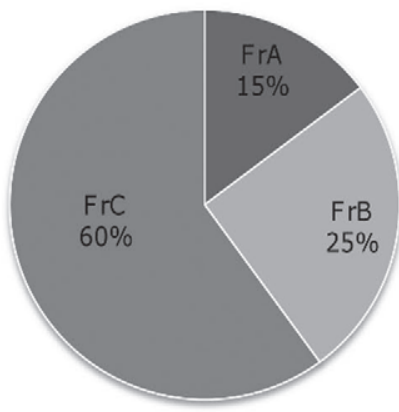

H77 cheeses, day 41

Figure 4. Reverse phase-HPLC profiles of water-soluble extracts during ripening of cheese manufactured with Lactobacillus helveticus: (A) strain ITGLH1; (B) strain ITGLH77; and (C) changes in areas of fractions (Fr) A, B, and C represented as percentage at d 1 and 41 of ripening for both types of cheeses. $\mathrm{Rt}=$ retention time.

at $\mathrm{d} 1$ ); nevertheless, the number of identified peptides from $\alpha_{\mathrm{s} 1}-\mathrm{CN}$ was higher compared with $\mathrm{H} 1$ cheeses, and varied from $28.1 \%$ at $\mathrm{d} 1$ to $37.7 \%$ at $\mathrm{d} 41$. The number of peptides derived from $\alpha_{\mathrm{s} 2}-\mathrm{CN}$ was higher in $\mathrm{H} 77$ cheeses but remained constant throughout aging time (i.e., $18 \%$ at $\mathrm{d} 1$ and $16 \%$ at $\mathrm{d} 41$ ).

Regardless of casein origin and aging time, the number of the large peptides containing more than 20 ami- 
no acid residues was 1.33 times higher in $\mathrm{H} 77$ cheeses. Interestingly, even less numerous compared with those from $\beta$-CN, the peptides containing more than 20 amino acid residues arising from $\alpha_{\mathrm{s} 1^{-}}$and $\alpha_{\mathrm{s} 2}$ CN were only present in $\mathrm{H} 77$ cheeses. Half of the large peptides arising from $\beta-\mathrm{CN}$ were present in both cheeses.

\section{Cleavage Sites on Caseins}

Profiles of the peptide splitting sites greatly varied between both types of cheeses in terms of regions in which peptide bonds were cleaved. Thus, peptide bonds that were split were distributed all along the $\beta-\mathrm{CN}$ sequence (Figure 5, A and B) at d 1, 13, and 41, for both types of cheese. As expected, the highest number of common splitting sites was found for plasmin sites at amino acids $\mathrm{Lys}_{28}, \mathrm{Lys}_{29}, \mathrm{Lys}_{105}$, and $\mathrm{Lys}_{107}$, but more surprisingly at $\mathrm{Phe}_{52}, \mathrm{Asn}_{68}, \mathrm{Gln}_{72}, \mathrm{Leu}_{192}$, and $\mathrm{Tyr}_{193}$, which correspond to splitting sites specific for proteinases of L. helveticus (Sadat-Mekmene et al., 2011). Their frequency of cleavage was higher in H77 cheeses at $\mathrm{d} 1$ and 13. At d 41 the number of splitting sites increased, reflecting the activity of other types of enzymes, such as aminopeptidases released through lysis of bacterial cells.

Identified peptides derived from $\alpha_{\mathrm{s} 1} \mathrm{CN}$ were present into more limited zones of the casein sequence, mainly in the $\mathrm{N}$ - and $\mathrm{C}$-terminal regions in both cheeses; only a few peptides arose from the region between $\operatorname{Arg}_{90}$ and $\mathrm{Gly}_{126}$. Regarding the occurrence of the splitting sites at the beginning of the ripening (Figure 5, C and D), the most frequent peptide bond split was observed between the amino acid residues $\mathrm{Phe}_{23}-\mathrm{Phe}_{24}$, corresponding to the main action of the coagulant, cathepsin D, and proteinases of $L$. helveticus. Some splitting sites that can be attributed to proteinases of L. helveticus are located between $\mathrm{Leu}_{92}$ and $\mathrm{Lys}_{124}$. Some differences were observed in this region between $\mathrm{H} 1$ and $\mathrm{H} 77$ cheeses, with the presence in $\mathrm{H} 77$ cheeses of $\alpha_{\mathrm{s} 1}-\mathrm{CN}(93-102)$ at $\mathrm{d} 1$ and the presence of $\alpha_{\mathrm{s} 1}-\mathrm{CN}(114-123), \alpha_{\mathrm{s} 1}-\mathrm{CN}(11-22)$, $\alpha_{\mathrm{s} 1}-\mathrm{CN}(112-123), \alpha_{\mathrm{s} 1}-\mathrm{CN}(10-22)$, and $\alpha_{\mathrm{s} 1}-\mathrm{CN}(112-124)$ at $\mathrm{d} 13$ and not in $\mathrm{H} 1$ cheeses; only $\alpha_{\mathrm{s} 1}-\mathrm{CN}(108-114)$, $\alpha_{\mathrm{s} 1}-\mathrm{CN}(32-40)$, and $\alpha_{\mathrm{s} 1}-\mathrm{CN}(106-114)$ were identified in H1 cheeses at d 13.

Peptides were identified mainly in the C-terminal end (between $\mathrm{Tyr}_{100}$ and $\mathrm{Leu}_{207}$ ) of $\mathrm{\alpha}_{\mathrm{s} 2^{-}} \mathrm{CN}$ in both cheeses (Figure $5 \mathrm{E}$ and $\mathrm{F}$ ). The frequency of splitting was below 5 per peptide bond, confirming the few number of peptides identified from this casein in the WSE. However, the number of splitting sites observed in the C-terminal part of the $\alpha_{\mathrm{s} 2}$ - $\mathrm{CN}$ in the $\mathrm{H} 77$ cheeses was directed against 16 amino acids, whereas only 9 were concerned in H1. Splitting sites were slightly different between both cheeses, with $\alpha_{\mathrm{s}^{2}} \mathrm{CN}(67-74)$ observed only in $\mathrm{H} 1$ cheeses at $\mathrm{d} 1$, whereas $\alpha_{\mathrm{s} 2}-\mathrm{CN}(14-24)$ and $\alpha_{\mathrm{s} 2}-\mathrm{CN}(6-24)$ were only identified in $\mathrm{H} 77$ cheeses.

Surprisingly, even if most of the cleavage sites were common between both cheeses, only 33, 24, and 9 peptides from $\beta-, \alpha_{\mathrm{s}^{-}}$, and $\alpha_{\mathrm{s} 2^{-}} \mathrm{CN}$, respectively, were the same in the aqueous phase of both cheeses at the end of ripening (Supplemental Tables S1 to S3; available online at http://www.journalofdairyscience.org/). The cleavage sites in common were distributed throughout the sequence in the case of $\beta-\mathrm{CN}$, whereas they were only found in the N-terminal end of $\alpha_{\mathrm{s} 1}-\mathrm{CN}$ and the C-terminal end of $\alpha_{\mathrm{s}^{2}}$ CN.

\section{Dynamic of Stretchability of Emmental Cheese During Ripening}

The dynamic of stretchability of Emmental cheese was monitored throughout the ripening time (Figure $6 \mathrm{~A})$. The curve has a U-shape for both strains up to d 27 of ripening and reached a plateau thereafter. The scattering of the measures from d 1 to 6 for both cheeses could be due to the heterogeneity in the casein network at the beginning of ripening. During the aging in warm room, stretchability progressively increased during ripening for both types of cheeses. Moreover, stretching was significantly higher in $\mathrm{H} 77$ after cheeses were moved to the warm room. At the end of ripening (d 41), strands were $100 \mathrm{~mm}$ longer for the H77 cheeses.

\section{Confocal Microstructure of the Strands of Emmental Cheeses}

After stretching, the newly formed strands were visualized by confocal laser scanning microscopy at $d$ 1 and 41 of ripening for both cheeses. Representative views of the strands are shown at d 1 for $\mathrm{H} 77$ cheeses (Figure 6B, A and B) and for both cheeses at d 41 (Figure $6 \mathrm{~B}, \mathrm{C}$ and D). Sections of the strands showed that paracasein matrix (in green/light gray strands) formed the continuous phase and was in the form of linear fibers. The fat (red/dark grey roughly ovoid objects) occurred as elongated pools trapped between the paracasein fibers, exhibiting a similar orientation as the paracasein matrix. Such pools of fat are in agreement with the coalescence of liquid fat droplets, formed as a consequence of damage to the fat globule membrane during Emmental cheese making process (Lopez, 2005; Lopez et al., 2007). Most of the fat coalesced and was exuded during heating and melting of the cheeses before stretching. Some fat melting and rising to the surface was also noticed when the strands were submitted to the laser of the confocal microscope. Bacterial colonies 

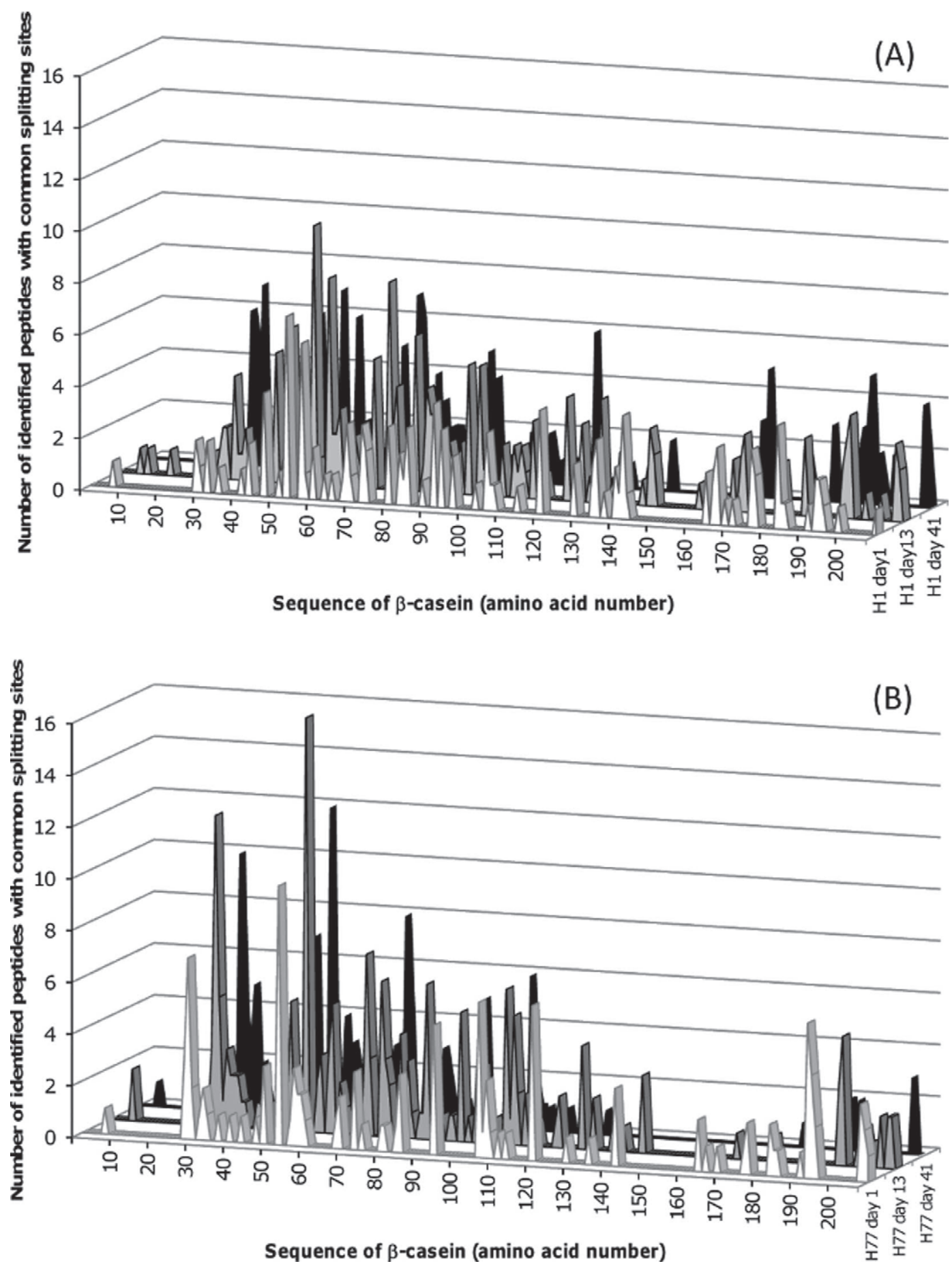

Figure 5. Distribution of cleavage sites along the casein sequences during cheese aging. For each peptide identified by liquid chromatographyelectrospray ionization-tandem MS, each time a peptide bond is cleaved a score of 1 is given to the amino acid corresponding to the $\mathrm{N}$ or $\mathrm{C}$ terminal end of the peptide produced, whereas the score of 0 is given to all other amino acids in the casein sequence. The number of times that a peptide bond has been identified as cleaved is summed and represented on the figure along the casein sequence: $\mathrm{A}$ and $\mathrm{B}=\beta$-casein; $\mathrm{C}$ and $\mathrm{D}$ $=\alpha_{\mathrm{s} 1}$-casein; and $\mathrm{E}$ and $\mathrm{F}=\alpha_{\mathrm{s} 2}$-casein, where $\mathrm{A}, \mathrm{C}$, and $\mathrm{E}$ show results for the $\mathrm{H} 1$ cheeses and $\mathrm{B}, \mathrm{D}$, and $\mathrm{F}$ for the $\mathrm{H} 77$ cheeses. 

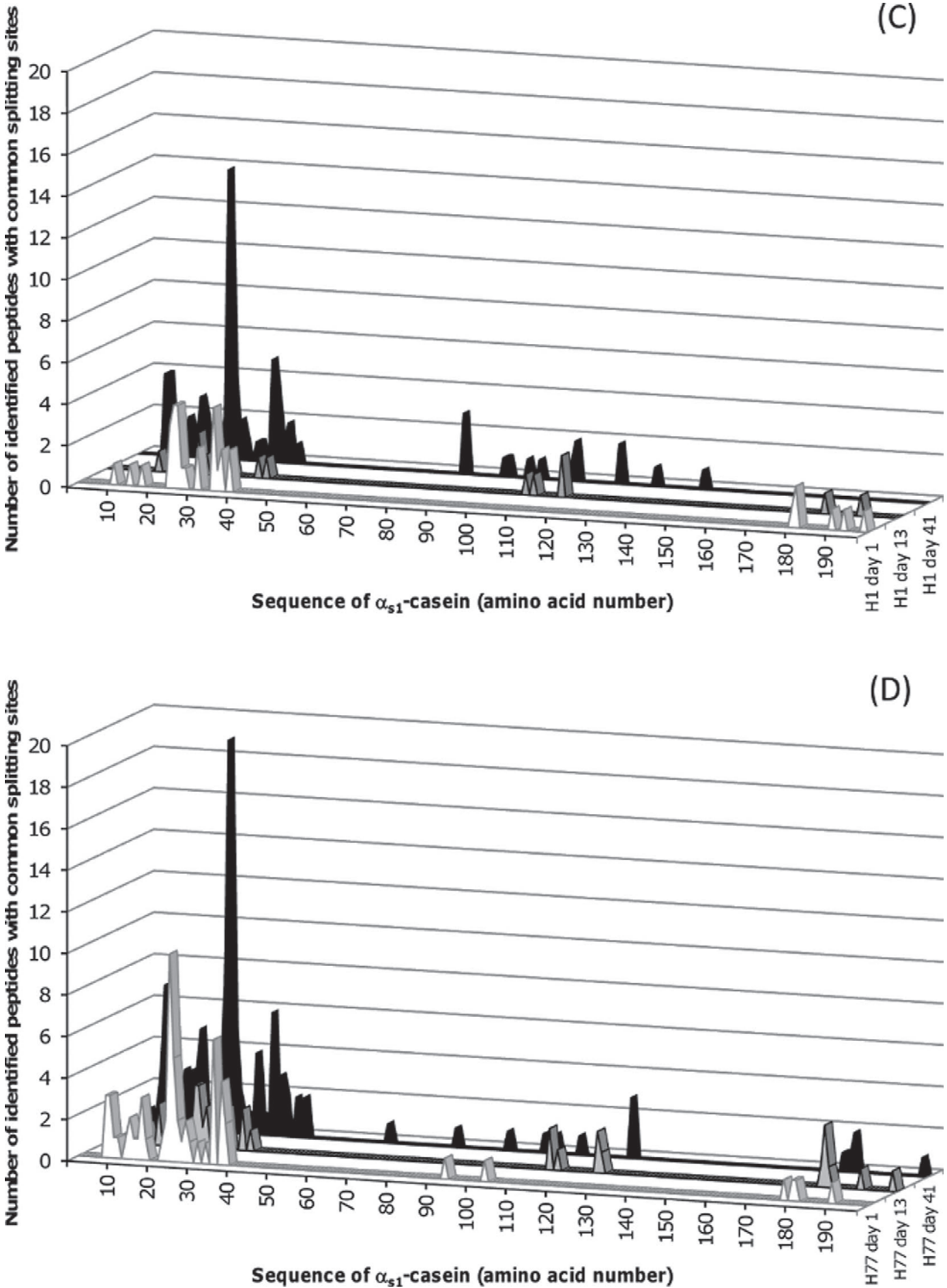

Figure 5 (Continued). Distribution of cleavage sites along the casein sequences during cheese aging. For each peptide identified by liquid chromatography-electrospray ionization-tandem MS, each time a peptide bond is cleaved a score of 1 is given to the amino acid corresponding to the $\mathrm{N}$ or $\mathrm{C}$ terminal end of the peptide produced, whereas the score of 0 is given to all other amino acids in the casein sequence. The number of times that a peptide bond has been identified as cleaved is summed and represented on the figure along the casein sequence: $\mathrm{A}$ and $\mathrm{B}=\beta$-casein; $\mathrm{C}$ and $\mathrm{D}=\alpha_{\mathrm{s} 1}$-casein; and $\mathrm{E}$ and $\mathrm{F}=\alpha_{\mathrm{s} 2}$-casein, where $\mathrm{A}, \mathrm{C}$, and $\mathrm{E}$ show results for the $\mathrm{H} 1$ cheeses and $\mathrm{B}, \mathrm{D}$, and $\mathrm{F}$ for the $\mathrm{H} 77$ cheeses. 

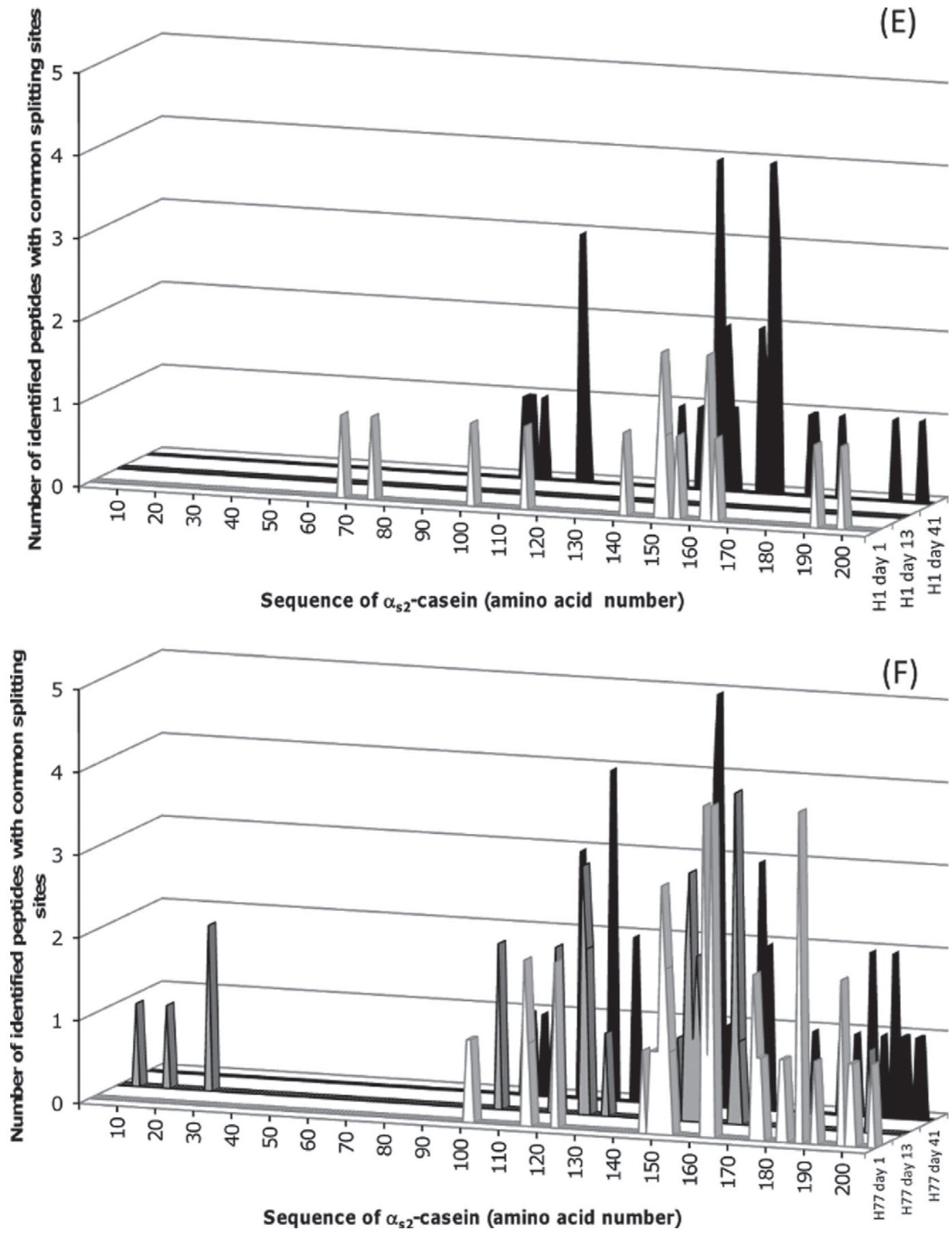

Figure 5 (Continued). Distribution of cleavage sites along the casein sequences during cheese aging. For each peptide identified by liquid chromatography-electrospray ionization-tandem MS, each time a peptide bond is cleaved a score of 1 is given to the amino acid corresponding to the $\mathrm{N}$ or $\mathrm{C}$ terminal end of the peptide produced, whereas the score of 0 is given to all other amino acids in the casein sequence. The number of times that a peptide bond has been identified as cleaved is summed and represented on the figure along the casein sequence: $\mathrm{A}$ and $\mathrm{B}=\beta$-casein; $\mathrm{C}$ and $\mathrm{D}=\alpha_{\mathrm{s} 1}$-casein; and $\mathrm{E}$ and $\mathrm{F}=\alpha_{\mathrm{s} 2}$-casein, where $\mathrm{A}, \mathrm{C}$, and $\mathrm{E}$ show results for the $\mathrm{H} 1$ cheeses and $\mathrm{B}, \mathrm{D}$, and $\mathrm{F}$ for the $\mathrm{H} 77$ cheeses. 
(A)
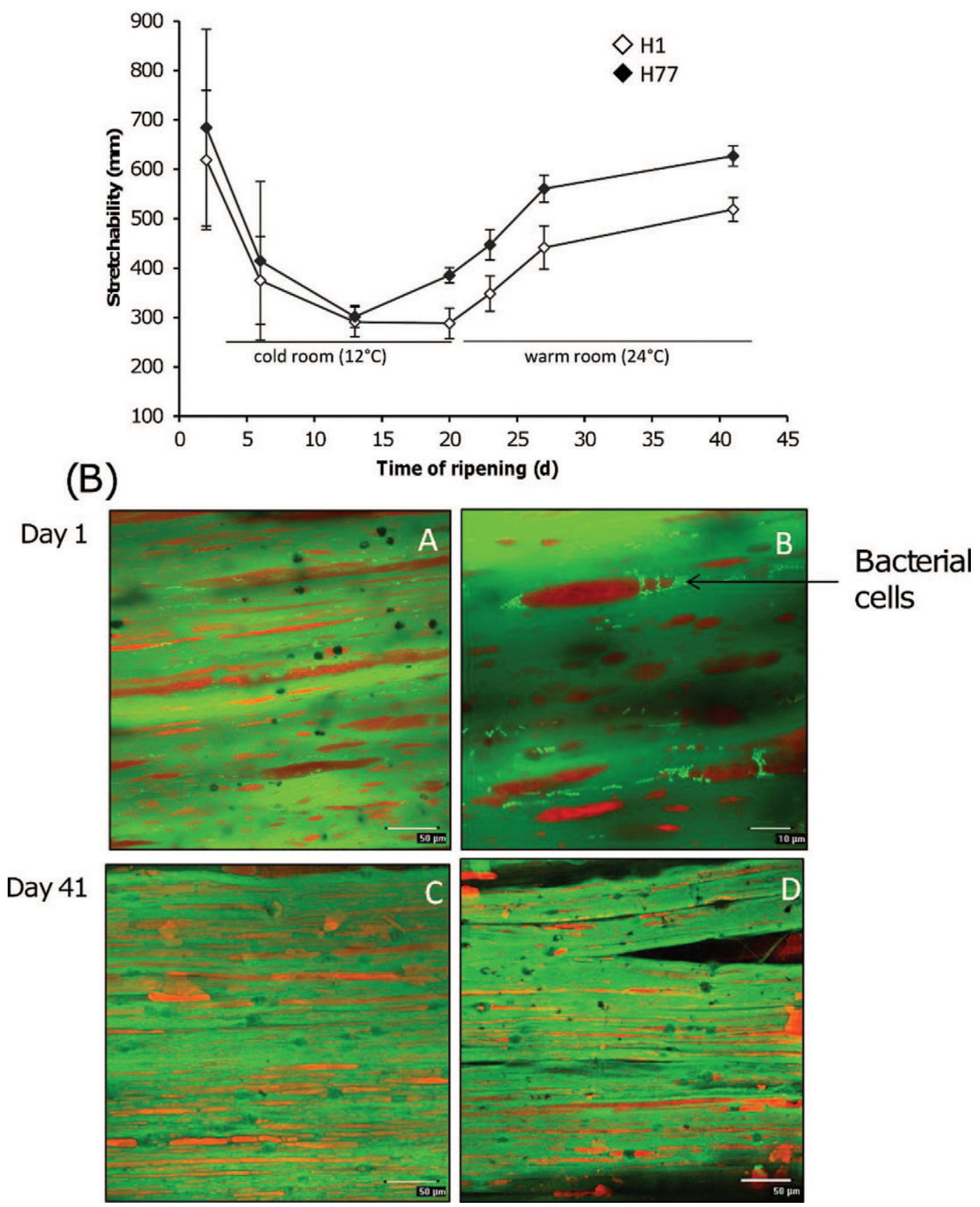

Figure 6. (A) Changes in stretchability during ripening of Swiss-type cheese manufactured using 2 strains of Lactobacillus helveticus: ITGLH1 and ITGLH77; (B) microstructures of the strands of Emmental cheeses manufactured using the strains of L. helveticus ITGLH1 and ITGLH77 by confocal laser scanning microscopy. Protein network is represented in green (light gray) strands, fat in red (dark gray) roughly ovoid objects inside the protein network, and bacterial colonies in light green (very light gray) small spheres located around the fat pools. Strands newly formed on d 1 were visualized with a $40 \times$ objective: (A) H77 cheese, (B) $4 \times$ zoom of a zone of the same cheese. Strands were visualized again at d 41 with a 10× objective: (C) H77 cheese, and (D) H1 cheese. Color version available in the online PDF. 
were found at $\mathrm{d} 1$ of ripening surrounding or in close contact with fat (Figure 6B, part B).

\section{Principal Component Analysis on Emmental Cheeses}

Principal component analysis allowed us to summarize the information in 2 dimensions, accounting $86 \%$ of the total variation. Figure 7A shows the scores of the individuals and Figure 7B a correlation circle of the variables. Principal component 1 explained most of the variation (78\%) and was related to cheese aging (Figure 7A). The young cheeses scored negatively and were correlated with the high presence of caseins (Figure 7B). The old cheeses scored positively and were well separated on the principal component 2 axis, which explained only $8 \%$ of the variation and may reflect the change in the peptide composition. At the end of ripening, $\mathrm{H} 77$ cheeses were correlated with the higher content of $\gamma-\mathrm{CN}$ and hydrophobic peptides (fraction C); H1 cheeses were correlated with smaller and hydrophilic peptides (\% NPN, fraction A) and a greater extent of autolysis. When stretching values were projected as supplementary data (available online at http://www. journalofdairyscience.org/), a positive correlation was observed with $\gamma$-CN, fractions B and C (large/medium and hydrophobic peptides) in agreement with the composition of $\mathrm{H} 77$ cheeses; and a negative correlation with PepX activity, the NPN/TN ratio, and fraction A (small peptides and amino acids) corresponding to $\mathrm{H} 1$ cheeses on the principal component 2 axis (Figure 7B).

\section{DISCUSSION}

A previous study on commercial cheeses (Gagnaire et al., 2001) showed that the thermophilic lactobacilli play a significant role in the Emmental proteolysis through the action of their CEP. Moreover, lactobacilli were shown to change the functional properties of the cheese (Oommen et al., 2002). More recently, the activities and specificities of a panel of 15 strains of L. helveticus were characterized under in vitro conditions, taking into account the number of proteinases synthesized by the strains (Genay et al., 2009). Rapid hydrolysis of pure $\beta$-CN was observed for all tested strains having 1 (PrtH2) or 2 CEP (PrtH and PrtH2), and the kinetics of pure $\alpha_{\mathrm{s} 1}$-CN hydrolysis was enhanced in presence of both CEP (Sadat-Mekmene et al., 2011). The number of casein-derived peptides identified when lactobacilli were grown in milk was severely reduced compared with that observed under in vitro conditions (Sadat-Mekmene et al., 2011). Therefore, knowing the distribution of the CEP and their specificities, that
A

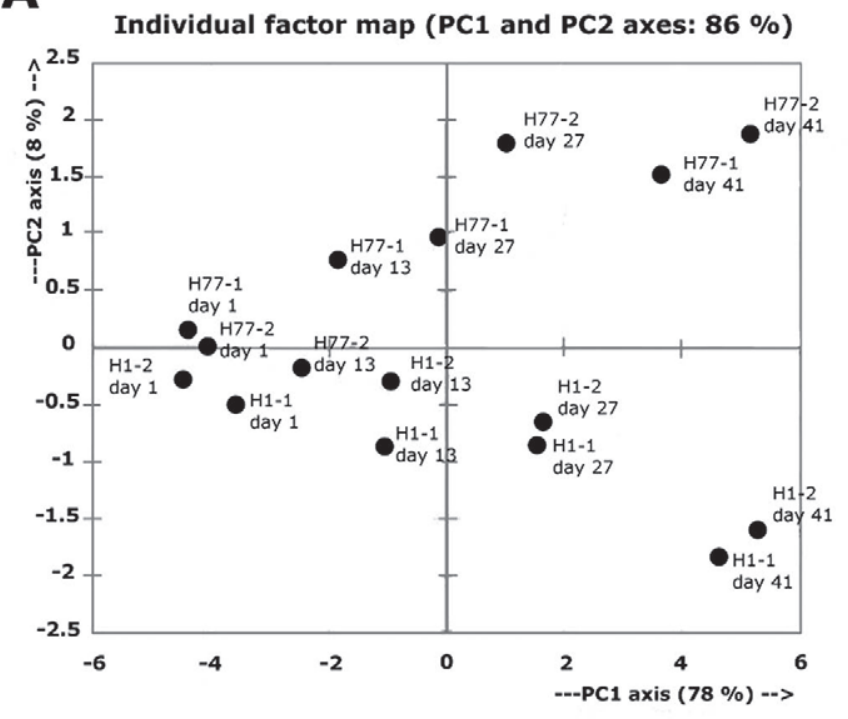

B

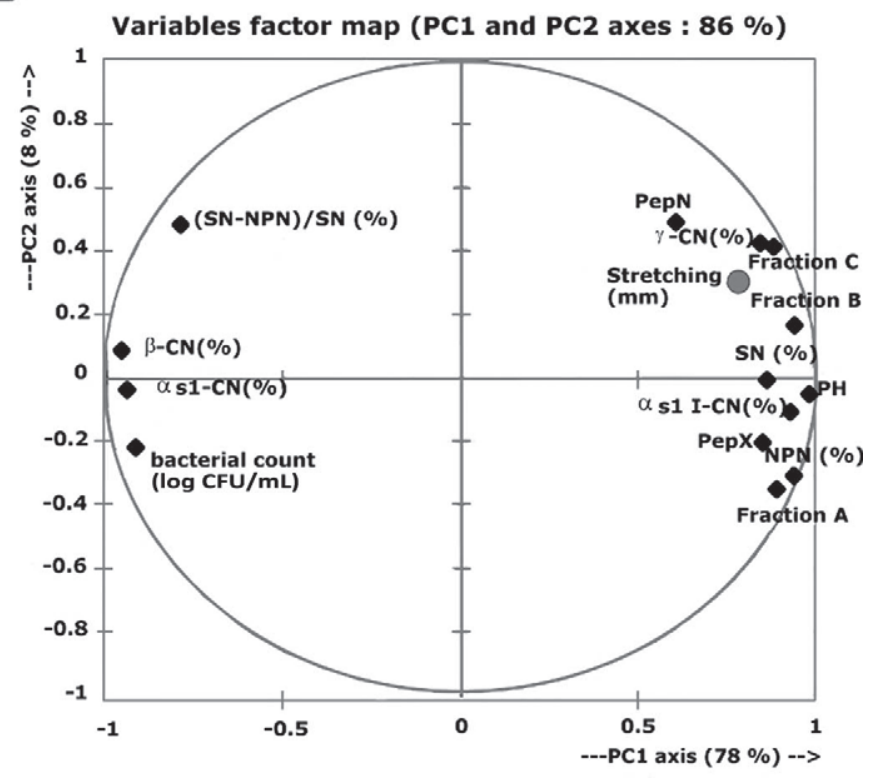

Figure 7. Principal component (PC) analysis showing the first 2 principal components of proteolytic data of Emmental cheeses manufactured using the strains of Lactobacillus helveticus ITGLH1 and ITGLH77: (A) individual attributes, and (B) variables. $\mathrm{SN}=\mathrm{pH}$ 4.6-soluble nitrogen; PepN and PepX= activity of intracellular aminopeptidase from L. helveticus released in cheese water-soluble extract. Stretching data (gray dot) are projected as supplementary data (available online at http://www.journalofdairyscience.org/).

study aimed to investigate the in situ proteolytic activity of $L$. helveticus for 2 strains having, respectively, 1 or 2 CEP: ITGLH77 (PrtH2) and ITGLH1 (PrtH2 and PrtH at least; Broadbent et al, 2011) in experimental Swiss-type cheeses. 
As lactobacilli, specifically L. helveticus, were shown to be responsible for enhanced stretching properties of Swiss-type cheeses (Richoux et al., 2009), an attempt was made to clarify the complex relationships between proteolysis due to L. helveticus and stretchability. Proteolysis was 1.5 times less extensive in cheese manufactured using $\mathrm{H} 77$ (having $1 \mathrm{CEP}$ ) as starter than using $\mathrm{H} 1$ (having $2 \mathrm{CEP}$ ), as shown by the NPN/TN ratio. This lower extent of proteolysis was especially noticeable for $\alpha_{\mathrm{s} 1}$-CN compared with $\beta$-CN. Proteolysis was restricted to accessible parts of the casein sequences, as shown in Figure 5.

The lower extent of proteolysis in $\mathrm{H} 77$ cheeses also resulted in the accumulation of hydrophobic peptides, present in fractions $\mathrm{B}$ and $\mathrm{C}$ of the chromatographic profile, in the urea-PAGE ( $\gamma$ - and $\alpha_{\mathrm{s} 1}-\mathrm{I}-\mathrm{CN}$ or derived), and in Tris-tricine SDS-PAGE, where some oligopeptides $>10 \mathrm{kDa}$ were observed. Regardless of the casein origin, the number of the peptides identified by MS/MS containing more than 20 AA was 1.3 times higher in $\mathrm{H} 77$ cheeses, and the peptides containing more than 20 amino acid residues arising from $\alpha_{\mathrm{s} 1^{-}}$and $\alpha_{\mathrm{s} 2}$ CN were only present in $\mathrm{H} 77$ cheeses.

However, differences between $\mathrm{H} 1$ and $\mathrm{H} 77$ cheeses cannot be attributed solely to the CEP activity, but also to the overall proteolytic enzymes. In fact, lysis of the bacterial cells was found as early as d 2 of aging, releasing part of the intracellular-located enzymes into the cheese aqueous phase. This lysis was much lower for the H77 cheeses than for the H1 cheeses, coherent with the lower amount of the fraction NPN/TN and the area of the peaks in the chromatographic fraction A, as well as the lower aminopeptidase and LDH activities observed.

Regarding the peptides produced, the cleavage sites were mainly restricted to those that were common for both strains and shown in a previous study (SadatMekmene et al., 2011). The fact that more peptides were identified in $\mathrm{H} 77$ cheese could be related to the lesser degree of lysis, which prevented peptides from being further hydrolyzed to amino acids. This was clearly shown in $\alpha_{\mathrm{s} 1} \mathrm{CN}$ derived peptides (Supplemental Table $\mathrm{S} 2$; available online at http://www.journalofdairy science.org/).

High stretchability was observed in both cheeses regardless of L. helveticus strains used, as seen in other studies (Guinee, 2002; Richoux et al., 2009). However, the dynamics of stretchability showed significant differences between both cheeses after d 20 of ripening - the H77 cheeses having the longest length of strands. The changes in nitrogen composition and proteolysis coincided with marked increases in the stretching properties of both cheeses; thus, the higher the proteolysis, the lower the stretching properties, as reported previously for mozzarella and Kashakaval (Guinee, 2002). However, a balance in the extent of proteolysis should also be reached to obtain longer strand length, as shown by the increase in stretchability observed during aging of $\mathrm{H} 77$ cheeses. Confocal laser scanning microscopy penetrates the cheese surface to visualize thin optical sections without disturbing the internal structure. It was the first time, to the best of our knowledge, that confocal microscopy was applied to strands of Emmental cheeses. The strands showed similar microstructure as mozzarella strands. Their features were not different enough to discriminate both cheeses at the optical level. Only differences with aging were found, with the fibers becoming more voluminous likely because of changes in peptide composition and, therefore, in hydration of the paracasein matrix.

The principal component analysis reinforced the initial hypothesis that stretchability was correlated with a peculiar type of peptides (i.e., hydrophobic peptides present in fractions $\mathrm{C}$ and $\mathrm{B}$ ). Thus, these hydrophobic peptides, among them large peptides from $\alpha_{\mathrm{s} 1^{-}}$and $\alpha_{\mathrm{s} 2^{-}}$ $\mathrm{CN}$ only found in the H77 cheeses, could be involved in forming the fibers of caseins through hydrophobic bonds between intact caseins and large peptides ( $\mathrm{Ri}-$ choux et al., 2009). Stretchability was also correlated to a lower value of proteolysis, which can be attributed to the presence of 1 CEP of the lactobacilli strains or lower release of intracellular peptidases into the cheese aqueous phase. As both phenomena cannot be distinguished, it remains difficult to definitively establish the role of the CEP of lactobacilli in the stretching properties of the Emmental cheeses. The role of CEP in the production of peptides, responsible for this technofunctional property, could be ascertained only by the use of mutants deficient in 1 or $2 \mathrm{CEP}$, which are not available at the present time.

\section{ACKNOWLEDGMENTS}

This work was supported by research grants from INRA (centre of Rennes, France) and the Brittany Region (Rennes, France; reference 08008390) and by a Fonds européen de développement régional (FEDER) program (Brittany region, Rennes, France; reference P0212-09007249).

\section{REFERENCES}

Artimo, P., M. Jonnalagedda, K. Arnold, D. Baratin, G. Csardi, E. de Castro, S. Duvaud, V. Flegel, A. Fortier, E. Gasteiger, A. Grosdidier, C. Hernandez, V. Ioannidis, D. Kuznetsov, R. Liechti, S. Moretti, K. Mostaguir, N. Redaschi, G. Rossier, I. Xenarios, and H. Stockinger. 2012. ExPASy: SIB bioinformatics resource portal. Nucleic Acids Res. 40:W597-603.

Broadbent, J. R., H. Cai, R. L. Larsen, J. E. Hughes, D. L. Welker, V. G. De Carvalho, T. A. Tompkins, Y. Ardö, F. Vogensen, A. De 
Lorentiis, M. Gatti, E. Neviani, and J. L. Steele. 2011. Genetic diversity in proteolytic enzymes and amino acid metabolism among Lactobacillus helveticus strains. J. Dairy Sci. 94:4313-4328.

Cogan, T. M., M. O'dowd, and D. Mellerick. 1981. Effects of pH and sugar on acetoin production from citrate by Leuconostoc lactis. Appl. Environ. Microbiol. 41:1-8.

Collin, J. C., J. L. Berdagué, M. Dognin-bergeret, and R. Grappin. 1987. Affinage et qualité du gruyère de Comté IV. Etude de la protéolyse. Lait 67:299-318.

Gagnaire, V., S. Lortal, and J. Léonil. 1998. Free active peptidases are detected in Emmental juice extracted before ripening in the warm room. J. Dairy Res. 65:119-128.

Gagnaire, V., D. Mollé, M. Herrouin, and J. Léonil. 2001. Peptides identified during Emmental cheese ripening: Origin and proteolytic systems involved. J. Agric. Food Chem. 49:4402-4413.

Gagnaire, V., M. Piot, B. Camier, J. P. C. Vissers, G. Jan, and J Léonil. 2004. Survey of bacterial proteins released in cheese: A proteomic approach. Int. J. Food Microbiol. 94:185-201.

Genay, M., L. Sadat, V. Gagnaire, and S. Lortal. 2009. prtH2, not prt $H$, is the ubiquitous cell wall proteinase gene in Lactobacillus helveticus. Appl. Environ. Microbiol. 75:3238-3249.

Goldbarg, J. A., and A. M. Rutenburg. 1958. The colorimetric determination of leucine aminopeptidase in urine and serum of normal subjects and patients with cancer and other diseases. Cancer 11:283-291.

Gripon, J. C., M. Desmazeaud, D. Le Bars, and J. L. Bergère. 1975. Etude du rôle des micro-organismes et de leurs enzymes dans la maturation des fromages. II. Influence de la présure commerciale. Lait 55:502-516.

Guinee, T. P. 2002. The functionality of cheese as an ingredient: A review. Aust. J. Dairy Technol. 57:79-91.

Hayes, M. G., J. C. Oliveira, P. L. H. McSweeney, and A. L. Kelly 2002. Thermal inactivation of chymosin during cheese manufacture. J. Dairy Res. 69:269-279.

Heiss, E. 1961. Versuche zur Bestimmung des Käsefettgehaltes mit Hilfe von Schnellmethoden. Deutsche Molkerei Zeitung 82:67-70.

Hong, Y. H., J. J. Yun, D. M. Barbano, and P. S. Kindstedt. 1998. Impact of three commercial lactobacillus culture strains on mozzarella cheese yield. Aust. J. Dairy Technol. 53:170-174.

IDF. 2001. Determination of nitrogen content. Standard No. 20. International Dairy Federation (IDF), Brussels, Belgium.

IDF. 2004. Cheese and processed cheeses: Determination of the total solid content. Standard No. 4. International Dairy Federation (IDF), Brussels, Belgium.

Kuchroo, C. N., and P. F. Fox. 1982. Fractionation of the water-soluble-nitrogen from Cheddar cheese: Chemical methods. Milchwissenschaft 37:651-653.

Lopez, C. 2005. Focus on the supramolecular structure of milk fat in dairy products. Reprod. Nutr. Dev. 45:497-511.

Lopez, C., B. Camier, and J. Y. Gassi. 2007. Development of the milk fat microstructure during the manufacture and ripening of Emmental cheese observed by confocal laser scanning microscopy. Int. Dairy J. 17:235-247.
Oberg, C. J., A. Wang, L. V. Moyes, R. J. Brown, and G. H. Richardson. 1991. Effects of proteolytic activity of thermolactic cultures on physical properties of mozzarella cheese. J. Dairy Sci. 74:389-397.

Oommen, B. S., D. J. McMahon, C. J. Oberg, J. R. Broadbent, and M. Strickland. 2002. Proteolytic specificity of Lactobacillus delbrueckii subsp. bulgaricus influences functional properties of mozzarella cheese. J. Dairy Sci. 85:2750-2758.

Pearce, K. N. 1977. The complexometric determination of calcium in dairy products. N.Z. J. Dairy Sci. Technol. 12:113-115.

Pederson, J. A., G. J. Mileski, B. C. Weimer, and J. L. Steele. 1999. Genetic characterization of a cell envelope-associated proteinase from Lactobacillus helveticus CNRZ32. J. Bacteriol. 181:45924597.

Richoux, R., L. Aubert, G. Roset, and J. R. Kerjean. 2009. Impact of the proteolysis due to lactobacilli on the stretchability of Swisstype cheese. J. Dairy Sci. Technol. 89:31-41.

Richoux, R., M. B. Maillard, J. R. Kerjean, S. Lortal, and A. Thierry. 2008. Enhancement of ethyl ester and flavour formation in Swiss cheese by ethanol addition. Int. Dairy J. 18:1140-1145.

Richoux, R., G. Roset, M. H. Famelart, and J. R. Kerjean. 2001. Diversité de quelques propriétés fonctionnelles à chaud de l'Emmental français. Lait 81:547-559.

Sadat-Mekmene, L., J. Jardin, C. Corre, D. Mollé, R. Richoux, M.-M. Delage, S. Lortal, and V. Gagnaire. 2011. Simultaneous presence of PrtH and PrtH2 proteinases in Lactobacillus helveticus strains improves breakdown of the pure $\alpha_{\mathrm{s} 1}$-casein. Appl. Environ. Microbiol. 77:179-186.

Schagger, H., and G. von Jagow. 1987. Tricine-sodium dodecyl sulfatepolyacrylamide gel electrophoresis for the separation of proteins in the range from 1 to $100 \mathrm{kDa}$. Anal. Biochem. 166:368-379.

Smeianov, V. V., P. Wechter, J. R. Broadbent, J. E. Hughes, B. T. Rodriguez, T. K. Christensen, Y. Ardo, and J. L. Steele. 2007. Comparative high-density microarray analysis of gene expression during growth of Lactobacillus helveticus in milk versus rich culture medium. Appl. Environ. Microbiol. 73:2661-2672.

Thierry, A., D. Salvat-Brunaud, M. N. Madec, F. Michel, and J. L. Maubois. 1998. Affinage de l'emmental: Dynamique des populations bactériennes et évolution de la composition de la phase aqueuse. Lait 78:521-542.

Valence, F., S. M. Deutsch, R. Richoux, V. Gagnaire, and S. Lortal 2000. Autolysis and related proteolysis in Swiss cheese for two Lactobacillus helveticus strains. J. Dairy Res. 67:261-271.

Valence, F., R. Richoux, A. Thierry, A. Palva, and S. Lortal. 1998. Autolysis of Lactobacillus helveticus and Propionibacterium freudenreichii in Swiss cheeses: First evidence by using species-specific lysis markers. J. Dairy Res. 65:609-620.

Yvon, M., C. Chabanet, and J. P. Pelissier. 1989. Solubility of peptides in trichloroacetic acid (TCA) solutions. Hypothesis on the precipitation mechanism. Int. J. Pept. Protein Res. 34:166-176. 